\title{
MANAJEMEN IMPLEMENTASI KURIKULUM 2013 DI MADRASAH
}

\author{
Yaya Suryana \\ Universitas Islam Negeri Sunan Gunung Djati Bandung \\ JI. A.H. Nasution No. 105, Cibiru Bandung, Jawa Barat, 40614 \\ Email: yayasuryana@uinsgd.ac.id

\section{Firman Yuda Pratama} \\ Universitas Islam Negeri Sunan Gunung Djati Bandung \\ Jl. A.H. Nasution No. 105, Cibiru Bandung, Jawa Barat, 40614 \\ Email: firmanyuda23@gmail.com
}

\begin{abstract}
ABSTRAK
Penelitian ini bertujuan untuk mengetahui dan mendeskripsikan manajemen implementasi kurikulum 2013 di Madrasah Tsanawiyah (penelitian di Madrasah Tsanawiyah Az-Zahra Kota Bandung). Metode yang digunakan dalam penelitian ini adalah metode deskriptif-kualitatif. Teknik yang digunakan dalam pengumpulan data adalah observasi, wawancara dan studi dokumentasi. Analisis data dilakukan dengan reduksi data dan penyajian data. Di Madrasah Tsanawiyah Az-Zahra Kota Bandung, peneliti menemukan beberapa fakta tentang kegiatan implementasi kurikulum 2013, yaitu kurikulum 2013 yang menjadi kurikulum inti dalam kegiatan belajar mengajar di madrasah tersebut dipadukan dengan kurikulum untuk memperkuat segi keagamaan siswa yang menjadi ciri khas pendidikan Islam yang ada di Indonesia. Berdasarkan hasil penelitian, manajemen implementasi kurikulum 2013 di Madrasah Tsanawiyah Az-Zahra Kota Bandung, yaitu: (1) perencanaan kurikulum 2013, (2) pengorganisasian kurikulum 2013, (3) implementasi kurikulum 2013, (4) evaluasi kurikulum 2013, (5) faktor penunjang dan penghambat implementasi kurikulum 2013, (6) hasil manajemen implementasi kurikulum 2013 di Madrasah Tsanawiyah Az-Zahra Kota Bandung.
\end{abstract}

Kata Kunci: Implementasi, Kurikulum 2013, Madrasah.

\section{ABSTRACT}

This study aims to find out and describe the management of the implementation of the 2013 curriculum in Madrasah Tsanawiyah (research in Madrasah Tsanawiyah Az-Zahra Bandung City). The method used in this research is descriptive-qualitative method. Techniques used in data collection are observation, interview and documentation study. Data analysis is done by data reduction and data presentation. In Madrasah Tsanawiyah Az-Zahra Bandung, researchers found some facts about the implementation of curriculum 2013, which is the curriculum of 2013 which became the core curriculum in teaching 
and learning activities in the madrasah is combined with the curriculum to strengthen the religious facet of students who characterize Islamic education in Indonesia. Based on the results of the study, the management of the implementation of the 2013 curriculum in Madrasah Tsanawiyah Az-Zahra Bandung, namely: (1) curriculum planning 2013, (2) organizing the curriculum 2013, (3) implementation of curriculum 2013, (4) evaluation of curriculum 2013, factors supporting and inhibiting the implementation of curriculum 2013, (6) the results of the implementation of the implementation of the 2013 curriculum in Madrasah Tsanawiyah Az-Zahra Bandung.

Keywords: Implementation, Curriculum 2013, Madrasah.

\section{PENDAHULUAN}

Pendidikan menurut Undang-Undang Nomor 20 tahun 2003 Tentang Sistem Pendidikan Nasional Pasal 1 ayat 1 menyatakan bahwa pendidikan adalah usaha sadar dan terencana untuk mewujudkan suasana belajar dan proses pembelajaran agar peserta didik secara aktif mengembangkan potensi dirinya untuk memiliki kekuatan sepiritual keagamaan, pengendalian diri, kepribadian, kecerdasan, akhlak mulia serta keterampilan yang diperlukan dirinya, masyarakat dan negara (UU No. 20 Tahun 2003).

Oemar Hamalik mendefinisikan pendidikan sebagai suatu proses dalam rangka mempengaruhi peserta didik supaya mampu menyesuaikan diri sebaik mungkin dengan lingkungannya dan dengan demikian akan menimbulkan perubahan dalam dirinya yang memungkinkannya untuk berfungsi secara adekwat dalam kehidupan masyarakat (Oemar Hamalik, 2014, h. 3).

Pendidikan di dalam masyarakat pada umumnya menggunakan jalur formal, pendidikan yang termasuk ke dalam jalur formal adalah pendidikan Islam, dan salah satu pendidikan Islam yang sering dijumpai di lingkungan masyarakat adalah madrasah. Madrasah adalah wadah atau tempat belajar ilmu-ilmu keislaman dan ilmu pengetahuan keahlian lainnya yang berkembang pada zamannya (Irawan, 2014, h. 129-131). Madrasah sebagai salah satu lembaga pendidikan yang ada di Indonesia mempunyai tujuan untuk mengembangkan potensi diri peserta didik agar memiliki kekuatan sepiritual keagamaan, pengendalian diri, kepribadian, kecerdasan, akhlak mulia serta keterampilan yang diperlukan dirinya, masyarakat dan negara (UU No. 20 Tahun 2003 Tentang Sistem Pendidikan Nasional Pasal 1 Ayat 1).

Untuk mencapai tujuan pendidikan tersebut, perlu adanya pengelolaan yang baik di suatu lembaga pendidikan. Pengelolaan ini biasanya disebut sebagai manajemen. Sondang P. Siagian dalam Andang, mendefinisikan manajemen sebagai kemampuan atau keterampilan untuk memperoleh suatu hasil dalam pencapaian tujuan melalui kegiatan-kegiatan orang lain (Andang, 2014, h. 21). Menurut Tafsir dalam rangka pencapaian tujuan pendidikan tersebut diperlukan adanya keterpaduan antara komponen-komponen pendidikan. Komponen-komponen tersebut yaitu: tujuan dan dasar, pendidik, peserta didik, kurikulum, metode, alat pendidikan dan evaluasi (Tafsir, 2011, h. 32). Salah satu proses pendidikan bisa berjalan dengan baik apabila memiliki komponen pendidikan yang lengkap dan utuh dan salah satu yang penting dari 
komponen-komponen tersebut adalah rancangan pendidikan atau sering disebut dengan kurikulum.

Menurut Irawan kurikulum adalah semua pengalaman, aktivitas, suasana dan segenap pengaruh yang diberikan kepada murid yang mereka kerjakan, mereka jumpai di sekolah serta di bawah pengawasan sekolah (Irawan, 2014, h. 121). Kurikulum bersifat dinamis karena selalu berubah-ubah sesuai dengan perkembangan dan tantangan zaman. Semakin maju peradaban suatu bangsa, maka semakin berat pula tantangan yang dihadapinya. Untuk menghadapi tantangan di dalam dunia pendidikan Indonesia, ketegasan kurikulum dan implementasinya sangat dibutuhkan untuk membenahi kinerja pendidikan yang jauh tertinggal dari negara-negara maju di dunia.

Digulirkannya Kurikulum 2013 yang diarahkan pada penciptaan kemampuan siswa yang berhubungan dengan pengetahuan, sikap, keterampilan serta memperkuat karakter peserta didik diharapkan mampu menjunjung pendidikan Indonesia kearah yang lebih baik lagi. Kurikulum 2013 ini sebenarnya melanjutkan pengembangan Kurikulum Berbasis Kompetensi yang telah dirilis tahun 2004 dengan mencakup kompetensi sikap, pengetahuan, dan keterampilan secara terpadu (Andang, 2014, h. 182-183). Untuk mensukseskan implemantasi kurikulum 2013 ini diperlukan manajemen kurikulum yang yang baik sebagai penunjangnya.

Menurut Rusman manajemen kurikulum ialah sebagian suatu sistem pengelolaan kurikulum yang kooperatif, komprehensif, sistematik dalam rangka mewujudkan ketercapaian tujuan kurikulum (Rusman, 2014, h. 3). Keberhasilan penerapan kurikulum 2013 harus didukung oleh berbagai pihak, mulai dari pemerintah, pendidik, tenaga kependidikan, peserta didik, dan masyarakat serta didukung oleh sarana dan prasarana yang memadai.

Pokok kegiatan utama manajemen kurikulum meliputi bidang perencanaan, pengorganisasian, implementasi, dan evaluasi kurikulum. Perencanaan kurikulum berdasarkan asumsi bahwa telah tersedia informasi dan data-data tentang masalah-masalah dan kebutuhan yang mendasari disusunnya perencanaan yang tepat. Pengorganisasian kurikulum berdasarkan asumsi bahwa untuk memudahkan pelaksanaan kerja diperlukan suatu kegiatan membagi tugas kepada orang-orang yang terlibat dalam kerja. Implementasi kurikulum berdasarkan asumsi bahwa usaha mengaktualisasikan kurikulum tertulis kedalam bentuk pembelajaran sehingga tujuan pendidikan dapat tercapai. Evaluasi kurikulum berdasarkan asumsi bahwa perencanaan, pengorganisasian, dan implementasi kurikulum saling memberikan informasi balikan yang akurat, sehingga dapat disusun beberapa langkah perbaikan.

\section{KAJIAN TEORI}

Rusman mendefinisikan manajemen kurikulum sebagai suatu sistem pengelolaan kurikulum yang kooperatif, komprehensif, sistemik, dan sistematik dalam rangka mewujudkan ketercapaian tujuan kurikulum. Ruang lingkup manajemen kurikulum meliputi perencanaan, pengorganisasian, implementasi, dan evaluasi kurikulum (Rusman, 2012, h. 3-4). Perencanaan kurikulum menurut Rusman adalah perencanaan kesempatan-kesempatan belajar yang dimaksudkan untuk membina siswa kearah perubahan tingkah laku yang diinginkan dan menilai sampai mana perubahan-perubahan telah terjadi pada 
siswa. Di dalam perencanaan kurikulum minimal ada lima hal yang mempengaruhi perencanaan dan pembuatan keputusan, yaitu: filosofis, konten/materi, manajemen pembelajaran, pelatihan guru, dan sistem pembelajaran (Rusman. 2012, h. 21). Pengorganisasian kurikulum merupakan upaya untuk mengelola dan mensingkronisasikan semua program kurikulum pendidikan agar dapat diimplementasikan dalam kegiatan belajar mengajar dengan optimal. Pengorganisasian kurikulum dapat dilihat dari dua pendekatan, yakni pendekatan manajemen dan pendekatan akademik. Implementasi kurikulum adalah manifestasi dari upaya untuk mewujudkan kurikulum yang masih bersifat dokumen tertulis menjadi serangkaian aktivitas pembelajaran. Menurut Hasan ada beberapa faktor yang mempengaruhi implementasi kurikulum, yaitu: karakteristik kurikulum, strategi implementasi, karakteristik penilaian, pengetahuan guru tentang kurikulum, sikap terhadap kurikulum, dan keterampilan mengarahkan. Sementara itu menurut Mars terdapat lima elemen yang mempengaruhi implementasi kurikulum, yaitu: dukungan dari kepala sekolah, dukungan dari rekan sejawat guru, dukungan dari siswa, dukungan dari orang tua, dan dukungan dari dalam diri guru adalah unsur yang utama (Rusman, 2012, h. 74). Evaluasi kurikulum adalah proses pengukuran keberhasilan kurikulum yang diterapkan pada suatu lembaga pendidikan yang berkaitan dengan program-program kurikulum. Evaluasi ini pada umumnya berfungsi sebagai cara untuk meningkatkan prestasi lembaga, pendidik, dan peserta didik melalui program-program pendidikan yang telah dilaksanakan.

Empat pertanyaan pokok pengembangan kurikulum, yakni:

a. Tujuan apa yang harus dicapai sekolah?

b. Bagaimanakah memilih bahan pelajaran guna mencapai tujuan itu?

c. Bagaimanakah bahan disajikan agar efektif diajarkan?

d. Bagaimanakah efektivitas belajar dapat dinilai?

Menurut Nana Syaodih tujuan kurikulum dirumuskan berdasarkan dua hal, pertama perkembangan tuntutan, keutuhan kondisi masyarakat. Kedua, didasari oleh pemikiran-pemikiran terarah pada pencapaian-pencapaian nilainilai filosofis, terutama falsafah negara. Adapun kategori tujuan pendidikan, yaitu tujuan umum dan khusus, jangka panjang, menengah, dan pendek (Syaodih, 2012, h. 103).

Materi atau program dalam kurikulum pada hakikatnya adalah isi kurikulum atau konten kurikulum itu sendiri. Al-Basyir menyebutkan bahwa yang dimaksud materi adalah "Wayuqsadhu bil al-muhtawa al-muqarrarat aldirasiyah wa maudhu'aat al-at'alum" yakni tema-tema pembelajaran yang telah ditentukan, yang mengandung berbagai keterampilan baik yang bersifat aqliyah (knowledge), jasadiyah, dan berbagai cara mengkajinya atau mempelajarinya (Heri, 2012, h. 10).

Uhbiyati mengemukakan bahwa istilah metode secara sederhana sering diartikan cara yang cepat dan tepat. Secara etimologis, kata metode berasal dari kata meta dan hodos yang sering diartikan dengan melalui dan jalan dalam mengerjakan sesuatu. Oleh karena itu menurut Tafsir suatu metode senantiasa hasil eksperimen yang telah teruji. Sementara itu metode secara terminologis, diartikan oleh Hasan Langgulung sebagai suatu cara atau jalan yang harus dilalui untuk mencapai tujuan pendidikan (Heri, 2012, h. 14). 
Evaluasi kurikulum dimaksudkan untuk menilai suatu kurikulum sebagai program pendidikan untuk menentukan efisiensi, efektivitas, relevansi dan produktivitas program dalam mencapai tujuan pendidikan yang telah ditetapkan. Efisiensi berkenaan dengan penggunaan waktu, tenaga, sarana dan sumbersumber lainnya secara optimal. Efektivitas berkenaan dengan pemilihan atau penggunaan cara atau jalan utama yang paling tepat dalam mencapai tujuan. Relevansi berkenaan dengan kesesuaian suatu program dan pelaksanaannya dengan tuntutan dan kebutuhan, baik dari kepentingan masyarakat maupun peserta didiknya. Sedangkan produktivitas berkenaan dengan optimalnya hasil yang dicapai dari suatu program. Menurut Nana Sudjana, dalam kurikulum itu ada beberapa aspek yang perlu di evaluasi, yaitu: program pendidikan, meliputi penilaian terhadap tujuan, isi program dan strategi pembelajaran (Gunawan, 2014, h. 117-118).

Pelaksanaan atau implementasi dalam Kamus Besar Bahasa Indonesia diartikan sebagai pelaksanaan atau penerapan. Sementara itu, menurut Fullan implementasi adalah proses mempraktekkan atau menerapkan suatu gagasan, program, atau kumpulan kegiatan yang baru bagi orang-orang yang berusaha atau diharapkan untuk berubah (Majid, 2014, h. 6).

Implementasi kurikulum menurut Hasan diartikan sebagai usaha merealisasikan ide, konsep, dan nilai-nilai yang terkandung dalam kurikulum tertulis menjadi kenyataan. Menurut Saylor dan Alexander implementasi kurikulum adalah proses menerapkan rencana kurikulum (program) dalam bentuk pembelajaran, melibatkan interaksi siswa dengan guru dan dalam konteks persekolahan. Sedangkan menurut Majid implementasi kurikulum adalah operasionalisasi konsep kurikulum yang masih bersifat potensial (tertulis) menjadi aktual dalam bentuk kegiatan pembelajaran. Dengan kata lain, implementasi kurikulum merupakan hasil terjemahan guru terhadap kurikulum yang dijabarkan ke dalam silabus dan rencana pelaksanaan pembelajaran (RPP) sebagai rencana tertulis (Majid, 2014, h. 7). Implementasi kurikulum 2013 di lembaga pendidikan adalah wujud dari diterapkannya kurikulum 2013 di lembaga pendidikan yang ada di Indonesia.

Menurut Peraturan Pemerintah Republik Indonesia Nomor 17 Tahun 2010 Tentang Pengelolaan dan Penyelenggaraan Pendidikan Pasal 1 Ayat 11 Madrasah Tsanawiyah yang selanjutnya disingkat MTs adalah salah satu bentuk satuan pendidikan formal dalam binaan Menteri Agama yang menyelenggarakan pendidikan umum dengan kekhasan agama Islam pada jenjang pendidikan dasar sebagai lanjutan SD, MI, atau bentuk lain yang sederajat atau lanjutan dari hasil belajar yang diakui sama atau setara SD atau MI (Peraturan Pemerintah RI Nomor 17 Tahun 2010 Tentang Pengelolaan dan Penyelenggaraan Pendidikan Pasal 1 Ayat 11).

Menurut Zakiah Darajat Madrasah Tsanawiyah adalah lembaga pendidikan yang memberikan pendidikan dan pengajaran tingkat menengah pertama dan menjadikan mata pelajaran Agama Islam sebagai mata pelajaran dasar yang sekurang-kurangnya $30 \%$ di samping mata pelajaran umum (Zakiah Darajat, dkk, 2011, h. 104). 


\section{METODOLOGI}

Penelitian ini merupakan penelitian kualitatif dengan metode deskriptif. Pada penelitian ini, peneliti merupakan instrumen kunci pengumpul data. Tahapan pengumpulan data meliputi wawancara, observasi, dan studi dokumentasi atau menyalin dokumen. Sumber data utama dalam penelitian ini adalah Kepala Madrasah Tsanawiyah Az-Zahra Kota Bandung. Tahapan analisis data pada penelitian ini yaitu: 1) menentukan pendekatan penelitian dan jenis data; (2) menentukan sumber data; (3) menentukan metode penelitian dan teknik pengumpulan data; (4) menganalisis data; dan (5) pengecekan keabsahan data melalui perpanjangan keikutsertaan, ketekunan pengamatan, triangulasi pengumpulan data dan triangulasi sumber data, pemeriksaan teman sejawat, analisis kasus negatif, kecukupan referensi, pengecekan anggota, urai rinci, auditing untuk kriteria kebergantungan, dan auditing untuk kriteria kepastian

\section{HASIL DAN PEMBAHASAN \\ Perencanaan implementasi kurikulum 2013}

Perencanaan kurikulum menurut Oemar Hamalik adalah suatu proses sosial yang kompleks yang menuntut berbagai jenis dan tingkat pembuatan keputusan (Oemar, 2010, h. 152). Hal tersebut terdiri dari rapat penyusunan rencana implementasi kurikulum 2013 madrasah, evaluasi atau revisi rencana implementasi kurikulum 2013 madrasah, dan sosialisasi implemantasi kurikulum 2013 kepada pendidik di madrasah.

Tahapan pertama dalam perencanaan implementasi kurikulum 2013 ini adalah rapat penyusunan rencana implementasi kurikulum 2013, dalam hal ini kepala madrasah terlebih dahulu mengirimkan beberapa wakil guru untuk mengikuti sosialisai atau publikasi mengenai implementasi kurikulum 2013 yang diselenggarakan oleh pemerintah di Kantor Kementrian Agama dan Kantor Departemen Keagamaan. Setelah itu kepala madrasah beserta guru-guru melakukan rapat penyusunan rencana implementasi kurikulum 2013 madrasah. Rapat ini biasanya dilaksanakan pada awal tahun ajaran baru atau sebelum proses belajar mengajar di madrasah dimulai. Dalam rapat penyusunan implementasi Kurikulum 2013 ini membahas kurikulum seperti apakah yang akan diterapkan selama satu tahun kedepan, target apa saja yang ingin dicapai dalam implementasi kurikulum 2013 di madrasah.

Tahapan kedua dalam perencanaan implementasi kurikulum 2013 ini adalah evaluasi atau revisi rencana implementasi kurikulum 2013 madrasah, dalam hal ini kepala madrasah beserta guru-guru di madrasah melakukan evaluasi atau revisi tentang kurikulum yang belum sesuai dengan rencana atau target awal direncanakannya implementasi kurikulum 2013. Hal ini dilakukan untuk memperbaiki kurikulum tertulis yang masih belum memenuhi syarat atau target yang ingin dicapai oleh madrasah. Tujuan diadakannya evaluasi atau revisi rencana implementasi Kurikulum 2013 ini yaitu untuk mengatahui kekurangan-kekurangan apa saja yang perlu diperbaiki dalam penyusunan rencana implementasi kurikulum di Madrasah Tsanawiyah Az-Zahra Kota Bandung dan untuk mengetahui sejauh mana pencapaian target yang diinginkan oleh pengimplementasian Kurikulum 2013 di madrasah yang telah disusun sebelumnya. 
Tahapan ketiga dalam perencanaan implementasi kurikulum 2013 adalah sosialisasi implemantasi kurikulum 2013 kepada pendidik di madrasah, dalam hal ini kepala madrasah mensosialisasikan kurikulum 2013 yang akan di laksanakan di madrasah kepada para pendidik sebagai pelaksana kurikulum 2013 tertulis yang telah direncanakan sebelumnya, agar dalam pelaksanaannya berjalan dengan lancar dan sesuai dengan apa yang menjadi target atau tujuan awal diadakannya implementasi Kurikulum 2013 di madrasah.

\section{Pengorganisasian kurikulum 2013}

Pengorganisasian kurikulum merupakan upaya untuk mengelola dan mensingkronisasikan semua program kurikulum pendidikan agar dapat diimplementasikan dalam kegiatan belajar mengajar dengan optimal. Pengorganisasian kurikulum dapat dilihat dari dua pendekatan, yakni pendekatan manajemen dan pendekatan akademik (Zaenul, 2013, h. 34-35).

Pengorganisasian kurikulum yang pertama yaitu kurikulum mata pelajaran terpisah yang ada di madrasah dikatakan semua mata pelajaran dipisah sesuai dengan jadwal serta kajiannya masing-masing dari mata pelajaran tersebut, kecuali mata pelajaran yang ada kaitannya atau memiliki kesamaan dengan mata pelajaran yang sedang diajarkan bisa sesekali dimasukkan untuk menambah wawasan bagi siswa.

Pengorganisasian kurikulum yang kedua yaitu kurikulum yang berkorelasi dengan mata pelajaran yang ada di madrasah bermula dari adanya mata pelajaran yang hampir serupa dengan mata pelajaran lain, sehingga dari kedua mata pelajaran tersebut dapat digabungkan dalam sistem pembelajarannya oleh guru mata pelajaran di madrasah. Hal ini dikarenakan adanya kesamaan pembahasan atau kriteria yang ingin dicapai oleh mata pelajaran tersebut.

Pengorganisasian kurikulum yang ketiga yaitu kurikulum bidang studi yang ada di madrasah sebenarnya meliputi semua mata pelajaran yang diajarkan di madrasah namun, pada kenyataannya kebanyakan mata pelajaran yang bisa dijadikan core subject dan core saja, hanya mata pelajaran yang mempunyai kaitan dengan ilmu-ilmu keislaman, seperti: Pendidikan Agama: Bahasa Arab, Sejarah Kebudayaan Islam, Akidah Akhlak, Fiqih, dan Baca Tulis Al-Qur'an.

Pengorganisasian kurikulum yang ke-empat yaitu kurikulum berintegrasi terpadu yang ada di madrasah dijadikan sebagai sarana untuk membantu siswa memecahkan masalahnya dalam memahami suatu pelajaran yang membutuhkan berbagai kajian dari berbagai mata pelajaran tertentu yang diajarkan oleh guru. Kurikulum berintegrasi terpadu ini biasanya digunakan oleh para siswa untuk memecahkan masalah yang ada hubungannya dengan keislaman dan hubungannya dengan mata pelajaran yang membutuhkan hitung-hitungan.

Pengorganisasian kurikulum yang kelima yaitu kurikulum inti. Kurikulum inti yang digunakan di madrasah adalah Kurikulum 2013 yang ditetapkan oleh pemerintah untuk Madrasah Tsanawiyah atau yang Sederajat.

\section{Implementasi kurikulum 2013}

Dalam bukunya Zainul (2013, h. 39) implementasi kurikulum diartikan sebagai aktualisasi kurikulum tertulis dalam bentuk pembelajaran. Implementasi 
kurikulum merupakan suatu proses penerapan konsep, ide, program, atau tatanan kurikulum ke dalam praktek pembelajaran atau aktivitas-aktivitas baru, sehingga terjadi perubahan pada sekelompok orang yang diharapkan untuk berubah.

Implementasi Kurikulum 2013 yang dilakukan di madrasah, terlebih dahulu memperhatikan proses penerapan konsep, ide, program, atau tatanan kurikulum sesuai dengan kebijakan pemerintah, namun pada saat pelaksanaannya melihat situasi dan kondisi yang ada agar pelaksanaan pembelajaran dapat dilakukan dengan lancar.

Hal ini bisa dilihat dari adanya bahan/materi pembelajaran yang terlebih dahulu disusun sebelum pelaksanaan pembelajaran dimulai, guna memperlancar pelaksanaan pembelajaran baik itu di dalam ruangan ataupun pembelajaran yang dilaksanakan di luar ruangan. Bahan/materi pembelajaran ini dibuat sesuai dengan kebutuhan pembelajaran. Strategi dan metode pembelajaranpun disusun sebelum melakukan proses pembelajaran agar strategi dan metode yang digunakan tidak membosankan bagi para siswa yang sedang mengikuti pelajaran. Sarana dan prasaranapun disiapkan dengan matang walaupun masih banyak kekurangan disana-sini, namun pada dasarnya guru mampu mengatasinya dengan menggunakan cara lain untuk mengganti sarana dan prasarana yang kurang memadai dengan caranya masing-masing agar proses belajar mengajar yang dilakukan oleh guru bisa terus berjalan meskipun pada kenyataannya banyak yang tidak sesuai dengan harapan, karena sarana dan prasarana kurang mendukung untuk melakukan pembelajaran. Untuk sistem penilaian pembelajaran yang digunakan mengacu pada aspek kognitif, afektif, dan psikomotor siswa yang memang menjadi ciri khas penilaian kurikulum 2013, yang menekankan pada ketiga aspek tersebut untuk saling menguatkan satu dengan yang lainnya.

\section{Evaluasi implementasi kurikulum 2013}

Evaluasi kurikulum adalah proses pengukuran keberhasilan kurikulum yang diterapkan pada suatu lembaga pendidikan yang berkaitan dengan program-program kurikulum. Evaluasi ini pada umumnya berfungsi sebagai cara untuk meningkatkan prestasi lembaga, pendidik, dan peserta didik melalui program-program pendidikan yang telah dilaksanakan.

Evaluasi kurikulum yang dilakukan terhadap implementasi kurikulum 2013 di madrasah meliputi dua hal. Pertama evaluasi program pembelajaran, evaluasi ini dilakukan untuk mengevaluasi program-program pembelajaran yang telah dilaksanakan apakah sudah mencapai target dari program tersebut atau belum. Kedua evaluasi proses pelaksanaan pembelajaran, evaluasi ini dilakukan untuk mengetahui jalannya pelaksanaan pembelajaran yang sudah direncanakan pada awal tahun ajaran baru apakah berjalan dengan baik atau tidak.

Evaluasi kurikulum yang dilaksanakan di madrasah pada intinya untuk membuat proses manajemen kurikulum berjalan lebih baik dari sebelumnya. Hal ini dapat diketahui melalui evaluasi yang baik serta tepat pada sasaran evaluasi. Evaluasi ini dilakukan untuk mengetahui kekurangan apa saja yang terdapat dalam program pembelajaran dan pada proses pelaksanaan pembelajaran yang telah dilakukan. 


\section{Faktor Penunjang dan Penghambat Implementasi Kurikulum 2013}

Sumber daya manusia, metode pembelajaran, sarana dan prasarana, sosialisasi atau publikasi dan pembiayaan menjadi faktor pendukung implementasi kurikulum 2013 di Madrasah Tsanawiyah, karena tanpa adanya berbagai hal di atas niscahya implementasi kurikulum 2013 di Madrasah Tsanawiyah tidak akan berjalan lancar.

Sumber daya manusia menjadi salah satu faktor penghambat implementasi kurikulum 2013 di Madrasah Tsanawiyah dari segi peserta didik kurang disiplin dan dari segi tenaga pendidik atau tenaga administrasi kurangnya motivasi untuk bekerja dengan baik. Sarana dan prasarana yang masih kurang memadai juga menjadi faktor penghambat implementasi kurikulum 2013 di Madrasah Tsanawiyah, karena tanpa adanya sarana dan prasarana yang memadai kegiatan implementasi kurikulum 2013 tidak akan bisa berjalan dengan baik. Pembiayaan juga menjadi faktor penghambat implementasi kurikulum 2013, itu karena tanpa adanya pembiayaan kegiatan implementasi kurikulum 2013 pun tidak kan berjalan dengn lancar bahkan bisa jadi tidak akan berjalan.

\section{Hasil Manajemen Implementasi Kurikulum 2013 Di Madrasah Tsanawiyah}

Dari segi pengelolaan kurikulum dirasa sudah cukup baik, itu terbukti dari berjalan dengan lancarnya kegiatan pembelajaran di madrasah. Dari segi inovasi kurikulum yang dilakukan oleh madrasah yang diarahkan pada penguatan agama siswa dirasa hasilnya sudah cukup baik. Itu dibuktikan dengan keseharian para siswa yang mampu menghormati satu sama lain dan berperilaku sopan.

\section{SIMPULAN}

Berdasarkan hasil dan pembahasan penelitian yang telah diuraikan, maka didapat kesimpulan: 1) Perencanaan implementasi kurikulum 2013 yang dilakukan di Madrasah Tsanawiyah Az-Zahra Kota Bandung meliputi tiga hal utama, yaitu: rapat penyusunan rencana implementasi kurikulum 2013 madrasah, evaluasi atau revisi rencana implementasi kurikulum 2013 madrasah, dan sosialisasi implemantasi kurikulum 2013 kepada pendidik di madrasah. 2) Pengorganisasian implementasi kurikulum 2013 di Madrasah Tsanawiyah Az-Zahra Kota Bandung meliputi: kurikulum mata pelajaran terpisah, kurikulum yang berkorelasi dengan mata pelajaran, kurikulum bidang studi, kurikulum berintegrasi terpadu kurikulum inti. 3) Implementasi kurikulum 2013 yang dilakukan di Madrasah Tsanawiyah Az-Zahra Kota Bandung meliputi: bahan atau materi pembelajaran, strategi dan metode pembelajaran, sarana dan prasarana pembelajaran dan sistem penilaian pembelajaran. 4) Evaluasi implementasi kurikulum 2013 yang dilakukan di Madrasah Tsanawiyah Az-Zahra Kota Bandung meliputi: evaluasi program pembelajaran dan evaluasi proses pelaksanaan pembelajaran. 5) Faktor penunjang dan faktor penghambat implementasi kurikulum 2013 yang dilakukan di Madrasah Tsanawiyah AzZahra Kota Bandung. Adapun faktor pendukungnya yaitu: seluruh stakeholder mendukung, metode pembelajaran yang variatif, sarana dan prasarana yang cukup lengkap, pembiayaan dari Bantuan Operasional Sekolah (BOS). 
Sedangkan untuk faktor penghambatnya yaitu: peserta didik kurang disiplin, sumber daya manusia (SDM) terbatas dan kurangnya motivasi, sarana dan prasarana masih kurang lengkap dan pembiayaan atau anggaran terbatas. 6) Hasil dari Manajemen Implementasi Kurikulum 2013 di Madrasah Tsanawiyah Az-Zahra Kota Bandung, dari segi pengelolaan kurikulum sudah cukup baik, itu dibuktikan dengan kegiatan belajar mengajar yang berjalan dengan lancar di madrasah tersebut. Dari segi hasil inovasi kurikulum yang dilakukan oleh madrasah yang diarahkan pada penguatan agama siswa dirasa hasilnya sudah cukup baik. Itu dibuktikan dengan keseharian para siswa yang mampu menghormati satu sama lain dan berperilaku sopan kepada guru ataupun sesama siswa.

\section{REFERENSI}

Andang, (2014). Manajemen \& Kepemimpinan Kepala Sekolah. Yogyakarta: ArRuzz Media.

Arifin, Z., (2012). Konsep dan Model Pengembangan Kurikulum. Bandung: PT. Remaja Rosdakarya.

Darajat, Z., dkk, (2011). Ilmu Pendidikan Islam. Jakarta: Bumi Aksara.

Majid, A. (2014). Implementasi Kurikulum 2013. Bandung: Interes Media.

Fitri, A. Z. (2013). Manajemen Kurikulum Pendidikan Islam Dari Normatif, Filosofis Ke Praktis. Bandung: Alfabeta.

Gunawan, H. (2012). Kurikulum dan Pembelajaran Pendidikan Agama Islam. Bandung: Alfabeta.

, (2014). Pendidikan Karakter. Bandung: ALFABETA.

Hamalik, O. (2010). Manajemen Pengembangan Kurikulum. Bandung: PT. Remaja Rosdakarya.

\section{Aksara.}

(2014). Kurikulum dan Pembelajaran. Jakarta: PT Bumi

Irawan, (2014). Filsafat Manajemen Pendidikan Islam. Bandung: CP. Cendekiapratama.

Peraturan Pemerintah Republik Indonesia Nomor 17 Tahun 2010 Tentang Pengelolaan Dan penyelenggaraan Pendidikan.

Rusman, (2014). Manajemen Kurikulum. Jakarta: PT. RajaGrafindo Persada.

Sukmadinata, N. S. (2012). Pengembangan Kurikulum, Teori dan Praktek. Bandung: PT Remaja Rosdakarya.

Tafsir, A. (2011). Ilmu Pendidikan dalam Perspektif Islam. Bandung: Rosdakarya.

Undang-Undang Sistem Pendidikan Nasional No. 20 tahun 2003 tentang Sistem Pendidikan Nasional (Sisdiknas). 